\title{
'A mí, estos pleitos no me interesan': Carlos Saura's Llanto por un bandido and Banditry in the Ominous Decade
}

\author{
JEAN ANDREWS \\ University of Nottingham
}

Carlos Saura's Llanto por un bandido (1964) was his second feature film, his first in colour and his first international co-production. The film, made with minimal resources and an international cast, tells the story of the rise and fall of José María Hinojosa, the post-War of Independence bandit known as El Tempranillo because he led his own gang of outlaws while not yet out of his teens. Saura and his scriptwriter Mario Camus hit upon the theme of Spanish bandits, and El Tempranillo in particular, in a pragmatic attempt to produce a script which would not be turned down by the censors. The resultant film, however, lacks stylistic and narrative coherence because of post-production editing undertaken in Rome, over which the young Saura had no control. ${ }^{1}$ The deleterious effect of the scheduled editing was compounded by the actions of the Spanish censors. The opening sequence of the completed film, carefully constructed with reference to Goya's War of Independence engravings Los desastres de la Guerra and showing the public garrotting of a group of outlaws, was cut to ribbons and the negatives destroyed. ${ }^{2}$ This scene was to involve, among others, Luis Buñuel,

1 Augusto M. Torres and Vicente Molina-Foix, 'From Black Spain to Silver Bears, Part One' in Carlos Saura: Interviews, ed. Linda M. Willem (Jackson: Univ. Press of Mississippi, 2003), 3-16, 7. All interviews cited are reproduced as translated in Willem. [As this is an edited/collected work, we need you to give the title of Willem's piece and its full page references.] This is a collection of press interviews in Spanish which Willem has published in English translation. The original interviews do not have formal titles. I have used the chapter titles Willem gives in her book here and elsewhere. Each interview constitutes a chapter.

2 See Francisco de Goya, Desastres de la Guerra (Calcografía Nacional, Real Academia de Bellas Artes de San Fernando, Madrid http://www.realacademiabellasartessanfernando.com/es/goya/goya-en-la-calcografia-

nacional/desastres-de-la-guerra, accessed 8 May 2017;) plate 34 Por una navaja, plate 35 No se puede saber por qué for the executions and possibly also plate 64 Carretadas al cementerio for the cart in which the prisoners arrive. (I can only get a hyperlink to Desastres de la 
in a knowing reference to Un Chien andalou (1929), as the executioner; Alfonso Sastre, Luis García Berlanga and Juan Antonio Bardem as prisoners; and Antonio Buero Vallejo as the magistrate (alguazil). ${ }^{3}$ Of these, only brief shots of Buñuel and Buero Vallejo survive. ${ }^{4}$

Though the historical El Tempranillo and the 'José Maria' recorded in popular Anglo- and Francophone travelogues was much celebrated, Saura and Camus do not seek to present a conventionally heroic bandolero in the film narrative. They acknowledge consulting Prosper Mérimée's letters from Spain (1830-1833) and Théophile Gautier's Voyage en Espagne (1843), both readily accessible, and they tempered these accounts with Natalio Rivas' twentieth-century biography of the bandit and vestiges of $\mathrm{El}$ Tempranillo in popular song. ${ }^{5}$ Saura reports:

We chose as an image of El Tempranillo something without any historical fidelity. One has to realize that the greater part of that which surrounds El Tempranillo is legend. He is a character that one can use

Guerra as a whole, not to individual plates in the collection) Juan Carlos Rentero, 'Interview with Carlos Saura' in Carlos Saura: Interviews, ed. Willem, 22-31, 24 [Which article/interview are you referring to in this volume?]. [Please clarify this reference. Are you referring to readers to a publication such as a catalogue, or to a website? Or are these images reproduced in Willem's work? Further information is needed to assist the reader to locate these images. If the images are available online, it would be helpful to direct readers to them via hyperlink(s).]

3 Torres and Molina-Foix, 'Black Spain to Silver Bears', 7. [Insert the title of Willem's piece in this volume.] There is probably a slip of the pen in the translation of this 1968 interview with Saura by Augusto Torres and Vicente Molina-Foix. [Please clarify: do you mean 'in Willem's article/introduction in her edited volume'?] Will the clarification in footnote 1 cover this? I have omitted Willem from the comment here. The text mentions Buñuel as the hangman (verdugo, presumably) and Bardem et al. as the executioners, but this should probably have been translated as prisoners or executed, since there is only one executioner in the scene. This is Bunuel, and he can be seen checking the turning handles (the garrottes) on each mechanism as Buero Vallejo reads out the sentences. (see Marvin D'Lugo, The Films of Carlos Saura: The Practice of Seeing [Princeton: Princeton U. P., 1991], 48).

4 Saura's recollection in the early 1980s that the censorship of this scene related to the execution by garrotte of the communist Julián Grimau in April 1963 (though partly misplaced since Grimau was, in fact, executed by firing squad) is one reason why commentators have read Llanto as a gnomic commentary on the Franco regime. See Gail Bartholomew, 'The Development of Carlos Saura', Journal of the University Film and Video Association, 3 (1983), 15-33 (p. 24) and D'Lugo, The Films of Carlos Saura, 47.

5 See Prosper Mérimée, Lettres d'Espagne, préface de Gérard Chaliand (Bruxelles: Éditions Complexe, 1989); Prosper Mérimée, Viajes a España, trad., prólogo, notas \& cronología de Gabino Ramos González (Madrid: Aguilar, 1988). The historian, diarist, liberal politician and bullfighting aficionado Natalio Rivas Santiago published a biography of El Tempranillo, José María, 'El Tempranillo': historia documental de un bandido célebre (Madrid: Mediterráneo, 1945). Saura and Camus may also have read Natalio Rivas' La Escuela de Tauromaquia de Sevilla y otras curiosidades (Madrid: Gráficas Uguina, 1939) and his Toreros del romanticismo: anecdotario taurino (Madrid: Aguilar, 1947), both with prefaces by the great early twentieth-century matador, Juan Belmonte. See D'Lugo, The Films of Carlos Saura, 46
Commented [c1]: Please check that the form of this name is consistent throughout - whether as José María or José Maria.

It is deliberately not consistent throughout, it depends on where it is cited and in which language. The editors of the special edition and I thought about this and opted for José Maria as the standard form of reference to the mythologised bandit with José María for the historical bandit. I have amended José Maria in the final section on the Saura film to José María as Saura is dealing more or less with the real Hinojosa.

If you think this is too confusing, I could go back and standardise to José María throughout... 
easily; he has elements that are valid for any kind of bandit and that can be modified as the situation requires. He is an ambiguous character.

I also wanted to give an imaginary ambiance to the film, like the one that is felt in the towns where the actions of a hero are sung about, many such documents exist about José Maria, little 'aleluyas' in which his story is told. ${ }^{6}$

Saura's comment that he sought an image of El Tempranillo without any historical fidelity points to two significant factors: that the research he and Camus carried out was that of artists in pursuit of a suitable topic, in other words, in search of inspiration; and that, apart from Rivas, they used travelogues by French writers and indigenous folk tradition, not academic history, to provide a 'voice' for their bandit film. They were also young artists themselves and therefore much of what they invested in the screenplay and the resulting film is rooted in intuition rather than experience.

What is intuited in the film is drawn from a much broader canvas than that provided by Gautier, Mérimée and the 'aleluyas'. The film does nothing less than represent the effects of warfare on bandits, a generation older than El Tempranillo, who fought the French in the War of Independence and the impact of the postwar treatment of these bandits on El Tempranillo's decision-making. To provide a comprehensive contextualization for this film, it is necessary to explore more broadly perceptions of bandits as related in the early nineteenth-century literature of the aggressor culture, taking into account the impact of involvement in the Napoleonic Wars and its imprint on some significant authors; and to look at later representations of banditry in Spain, which are partly ripostes to French exoticizing accounts and partly attempts to redress perceived imbalances in the telling of Spanish history. Indeed, the casual glamorization of the figure of the bandit generally taken as a sine qua non of Anglo-Saxon and French travel writing of the early nineteenth century is not what it seems. Behind it lies a much more complex canvas.

Thus, while the intrusive editing of Saura's Llanto por un bandido and the censorship of the film's opening sequence make it difficult to arrive at clear conclusions as to how it projects the figure of the wrongdoer, this flawed and overlooked early Saura piece does provide a fascinating reading of the dilemma faced by the bandit in the Ominous Decade of 1823-33.

\section{'Any kind of bandit': The View from England, the US and France}

While it is very easy to dismiss early nineteenth-century travellers' tales of Spain as essentializing, exoticizing and patronizing, that would be grossly to underestimate their sensitivity to the host culture. The more enlightened

6 Bartholomew, 'The Development of Carlos Saura', 22 
narrators underscore this by highly-aware authorial self-ironizing and the texts offer a complex and often highly-detailed perspective on early nineteenth-century Spain. This is not to suggest that Gautier and Mérimée's accounts are immune to the Romantic propensity for embellishment and fantasy or that they were composed in ignorance of the work of travellers who preceded them. They depended in great measure on the work of their forebears. However, they do form part of a trajectory identifiable in French travel writing on Spain which moves, as the nineteenth century progresses, towards greater and greater focus on observed reality appropriately contextualized in the text. This is epitomized in Charles Davillier's detailed and scrupulous Voyage en Espagne (1874), with illustrations by Gustave Doré. ${ }^{7}$ Illustrations played a key role and Doré's gritty, realist drawings subsequently achieved a prominence beyond Davillier's travelogue. They were as important to Saura's and Camus' research as the work of Goya. ${ }^{8}$

Outside Spain, the bandit 'José Maria' was widely reported upon, by Anglo- and Francophone travellers, from the late 1820s. The future British prime minister and novelist Benjamin Disraeli made a diary entry for 1 July 1830, while in the Sierra de Ronda:

Here at Castelar we slept in the very haunt of the banditti, among the good fellows of Jose Maria, the captain Rolando of this part, and were not touched. [...] In spite of our frequent enquiries after the robbers, my being told 'that is one of them', or that 'Jose Maria was here two nights ago', or 'is expected here tonight', I was a little disappointed, I confess, to return quite safe, and really began to believe we had been half mystified. Judge then our feelings when, on re-entering the hotel, the first sight that meets us and the first sight that greets us, are two Englishmen just arrived from Cadiz, utterly rifled and stripped. ${ }^{9}$

A year earlier, the American historian, journalist and novelist, Washington Irving described, somewhat with his tongue in his cheek, precautions taken by himself and his companion, a Russian diplomat, on their journey towards Granada:

A couple of stout steeds were provided for our own mounting, and a third for our scanty luggage and the conveyance of a sturdy Biscayan

7 Charles Davillier, Voyage en Espagne (Paris: Hachette, 1874). These travel accounts were published in instalments in Le Tour du Monde between 1862 and 1873.

8 D'Lugo, The Films of Carlos Saura, 46.

9 Benjamin Disraeli, Home Letters Written by the Late Earl of Beaconsfield in 1830 and 1831, ed. Ralph Disraeli (London: John Murray, 1885), 13. Disraeli explains the Spanish bandit to his correspondents by referring to a fictional character from Alain-René Lesage's early eighteenth-century picaresque novel set in Spain, Gil Blas and real Italian banditsevidence of the primacy of France and Italy on the British Grand Tour, with Iberia very much a second rank destination at the time. 
lad, about twenty years of age, who was to be our guide, our groom, our valet, and at all times our guard. For the latter office he was provided with a formidable trabuco or carbine, with which he promised to defend us against rateros or solitary footpads; but as to powerful bands, like that of the 'sons of Ecija', he confessed they were quite beyond his prowess. He made much vainglorious boast about his weapon at the outset of the journey, though, to the discredit of his generalship, it was suffered to hang unloaded behind his saddle. ${ }^{10}$

Though Irving does not mention him by name, it is worth noting that in his early years, El Tempranillo was associated with 'Los niños de Écija', before branching out on his own. He might well have been one of those outlaws feared by the 'sturdy Biscayan lad'. These two Anglophone travelogues convey the expectation that encounters with bandits are an essential element of the Andalusian experience. Their accounts demonstrate that such encounters, if they occur, must be treated with the superior nonchalance of the educated gentleman.

It should be no surprise, therefore, that the fictional archaeologist narrator of Mérimée's novella Carmen, published in 1845 but set two decades earlier, observes this trope. He is not remotely perturbed when he comes across an individual he believes to be the very figure of 'José-Maria', at least as he is depicted in wanted posters. Trusting entirely to his own calm common sense, he plays down the panicked response of his guide-cumbodyguard who wishes to turn the bandit in for a reward, and instead shares food and cigars with him:

[...] à force de considérer mon compagnon, j'étais parvenu à lui appliquer le signalement de José-Maria, que j'avais lu affiché aux portes de mainte ville d'Andalousie. Oui, c'est bien lui ... Cheveux blonds, yeux bleus, grande bouche, belles dents, les mains petites; une chemise fine, une veste de velours à boutons d'argent, des guêtres de peau blanche, un cheval bai ... Plus de doute!11

Indeed, this description is not far removed from the watercolour sketches of El Tempranillo executed by the English painter and traveller John Frederick Lewis (1832; Museo del Bandolero, Ronda), though in the

10 The Alhambra (1851), in Washington Irving, Bracebridge Hall; Tales of a Traveller; The Alhambra, ed. Andrew B. Myers (New York: Library of America, 1991), 719-1050, 730 [Please provide the full page references of 'The Alhambra' in this volume].

11 '[...] as a result of looking at my companion, I managed to assign him the description of José Maria, which I had seen stuck to the gates of many Andalusian towns. Yes, it's certainly him ... Blond hair, blue eyes, large mouth, good teeth, small hands; a fine shirt, a velvet waistcoat with silver buttons, white leather gaiters, a bay horse ... No doubt about it!' (Prosper Mérimée, Carmen et autres nouvelles, vol 2, ed. Jean Mistler, [Paris: Livres de Poche, 1983], 175-247, 186; my translation). Does the modern edition have a named editor or an introduction? If so, please give details.] The edition I was using is actually a schools' edition so I have substituted a different one, with a named editor. 
sketches he is not quite as well-dressed. The encounter between painter and bandit is included in Llanto as the confirmation of El Tempranillo's spectacular success, though the rendition of the sketch itself in the film provides for a far more elaborately-attired bandit than the one depicted by Lewis.

As Disraeli's term banditti attests, the territory par excellence of the early nineteenth-century bandit was not Andalusia but the Italian Mezzogiorno or South and specifically, at the beginning of the nineteenth century, the kingdom of the Two Sicilies, for centuries a Spanish dominion. Mérimée, for example, featured the realm of Italianate banditry in his Corsican novella Colomba, published in book form in 1841. A significant and unique aspect of banditry in Spain and Italy in the early nineteenthcentury was the impact of the French invasions of these territories on the bandits themselves. Many found themselves becoming freedom fighters with the result that the line between soldier and outlaw was temporarily blurred. A particular instance occurs in the final work of the greatest of nineteenth-century historical adventure novelists, the elder Alexandre Dumas, known as Dumas père to distinguish him from his son Alexandre, also a novelist and playwright.

Dumas père had significant personal experience of the Mezzogiorno and of Spain. He explored Naples and Sicily in the mid 1830s and published a trilogy of travelogues: Le Speronare (1842), Le Capitaine Arena (1842) and Le Corricolo (1843). Politically liberal, he translated Giuseppe Garibaldi's memoirs into French two decades later in 1860 and visited Sicily in the same year to bring arms to the Spedizione dei Mille (Expedition of the Thousand). He visited Spain in the 1840s with his son and duly produced five volumes of travelogue. ${ }^{12}$ Towards the very end of his long writing life, however, his views on banditry in the Mezzogiorno veered away from the conventional Romantic clichés of his youth, informed, possibly, by the recollection of his father, General Thomas-Alexandre Davy de la Pailletrie's undoing in Sicily in 1799 when he himself was a very small child. Davy de la Pailletrie (sometimes also known as Alexandre Dumas) was born in Saint-Domingue to a French landowner and a black slave. He would become not only one of the most successful and dashing generals of the French Revolution but the most high-ranking officer of mixed race in the French army, achieving a grade which has yet to be equalled. Having been at odds with Napoleon during the ill-fated Egyptian campaign, he was shipwrecked off Sicily in 1799 as he returned to France and imprisoned for

12 Alexandre Dumas, Impressions de voyage: de Paris a Cadix 1847-48 (Paris: François Bourin, 1989). [Does this modern edition have a named editor or introduction? If it does please insert the details.] No editor. 
two years in atrocious conditions by an anti-Napoleonic citizen army. ${ }^{13}$ The imprisonment broke the general's once indomitable health and he died in 1806, when his son (Dumas père) was not yet four years old. The general's ordeal, at once a family sorrow and a matter of national political importance, particularly given Davy de la Pailletrie's totemic significance to the Revolution, is reflected in the Neapolitan episodes towards the end of Dumas père's final unfinished novel, Le Chevalier de Sainte-Hermine (1869-1870).

Unlike much of the work written at his peak, which was undertaken in collaboration with other writers under his direction, rather like the system used in a painter's workshop, this novel was entirely penned by himself in advanced years and penury. ${ }^{14}$ As Claude Schopp observes: 'c'est le vieil écrivain à l'approche de la mort qu'on entend' ('what we hear is the elderly writer facing death'). ${ }^{15}$ Set in 1804-1806, the eponymous hero, after many incredible adventures, becomes a chasseur de bandits (bandit hunter) in Calabria, then under the rule of Joseph Bonaparte, later King of Spain. Dumas takes the opportunity to disparage the governance of the Two Sicilies in the early 1800s under Ferdinand, son of Charles III of Spain, and his consort, Maria Carolina of Austria, daughter of the Holy Roman Emperor Francis I, and reserves some harsh words for the local bandits:

C'est, on le sait de temps immemorial, une habitude au pape de donner asile aux brigands qui désolent les États napolitains; ces brigands ne sont point un fléau éphémère mais une plaie inhérente au sol; dans les Abruzzes, dans la Basilicate, dans les Calabres, on naît brigands de père en fils, le brigandage est un état; on est brigand comme on est boulanger; seulement, pendant quatre mois de l'année on quitte le domicile paternel pour se faire gentilhomme de grands chemins; l'hiver les brigands restent tranquillement chez eux, sans que jamais personne ait l'idée d'aller les y troubler. Le printemps venu, ils essaiment, et chacun va reprendre son poste habituel. ${ }^{16}$

13 The Esercito della Santa Fede (Holy Faith Army) was a popular militia constituted in 1799 by Cardinal Fabrizio Ruffo to liberate Naples from Revolutionary French forces and re-instate Ferdinand IV and the primacy of the Catholic Church.

14 Claude Schopp, 'Le Testament perdu', in Alexandre Dumas, Le Chevalier de SainteHermine, ed. \& annoté par Claude Schopp (Paris: Phébus, 1995), 13-71 (p. 29; my translation).

15 Schopp, 'Le Testament perdu', 70

16 'It is, we know from time immemorial, a custom for the Pope to give asylum to the brigands who lay waste the Neapolitan States; these brigands are certainly not an ephemeral blight but an ulcer inherent to the soil; in Abruzzo, in Basilicata, in Calabria, you are born a brigand from father to son, brigandry is a state; you are a brigand in the same way you are a baker; except, during four months of the year you leave your parental home in order to become a gentleman of the highways; in winter brigands stay peacefully at home, with nobody ever having had the idea of going to trouble them there. Spring come again, they spread out, and each one goes back to his usual post' (Dumas, Le Chevalier de Sainte- 
While Dumas encapsulates here the accepted nineteenth-century view of the South of the Italian peninsula and the islands as congenitally prone to banditry, with no sense of its being anything but an occupation like any other, his characterization of the activity as an ulcer is unusually negative. In this context of bandit hunting, he mentions another notable Napoleonic general, Joseph Léopold Hugo, who would play a major part in the French occupation of the Iberian Peninsula, being created Duke of Sigüenza by Joseph Bonaparte in 1810. Dumas notes in Le Chevalier de Sainte-Hermine that he was the officer who brought about the capture of the most notorious Neapolitan brigand-turned-anti-French insurgent, Michele Prezza, also known as Fra Diavolo, in $1806 .{ }^{17}$ In a footnote in the same chapter, Dumas claims, erroneously, that Hugo also caught the most notorious 'bandit' in French-occupied Spain, the guerrilla leader and later field marshal, Juan Martín Díez, known as El Empecinado. ${ }^{18}$ Unlike Prezza, Díez had not been a brigand before the French invasion and, indeed, Dumas may have misinterpreted General Hugo's memoirs. Even so, at a time when guerrilla warfare was in its infancy in Sicily and in Iberia, the distinction between career bandits turned freedom fighters and respectable citizens employing the tactics of banditry for political ends was not clearly drawn. ${ }^{19}$

It is ironic then that the 1830s barnstormer, Hernani, by Victor Hugo, the son of General Joseph Léopold Hugo, should be such a celebration of brigandry. Born in the same year as Dumas, Victor Hugo spent time in Spain in 1811 as a nine-year-old while his father was failing to counteract El Empecinado. ${ }^{20}$ Indeed, a contemporary British account claims that El Empecinado 'outgeneralled' Joseph Léopold Hugo at every level. ${ }^{21}$ Jean René Aymes comments on the reluctance of French nineteenth-century writers to engage, particularly in historical fiction, with the war in Iberia:

Por parte francesa, esa guerra de España, perdida, ilegítima y creadora de una mala conciencia nacional no podía dar lugar al despliegue de un

Hermine, ed. Schopp, 901; my translation). This novel arguably the completion of a trilogy on the post-Revolutionary and Napoleonic years, which he began with Les Compagnons de Jéhu in 1857, followed by Les Blancs et les Bleus a decade later.

17 Dumas, Le Chevalier de Sainte-Hermine, ed. Schopp, 944-47.

18 Dumas, Le Chevalier de Sainte-Hermine, ed. Schopp, 247, 1096.

19 Dumas, Le Chevalier de Sainte-Hermine, ed. Schopp, 947.

20 María Victoria Rodríguez Navarro, 'Hugo y Mérimée: entre la España imaginada y la España vivida', in La cultura del otro: español en Francia; francés en España/La Culture de l'autre: espagnol en France; français en Espagne, coord.. Manuel Bruña Cuevas, María de Gracia Caballos Bejano, Inmaculada Illanes Ortega, Carmen Ramírez Gómez \& Anna Raventós Barangé (Sevilla: Univ. de Sevilla, 2006), 667-77 (p. 668), $<$ http://www.culturadelotro.us.es/actasehfi/pdf/3rodriguezn.pdf $>$ (accessed 7 March 2016).

21 A General Officer, The Military Exploits of Don Juan Martin Diez, 'The Empecinado' (London: Carpenter and Son, 1823), 90, 101. The same officer provides a translation of the letter Díez presented to Fernando VII on 13 February 1815, challenging the king's autocratic behaviour and demanding the restitution of the Cadiz Constitution. He was lucky merely to be condemned to exile in Valladolid. 
fresco histórico-novelesco tan rico y amplio como el que compuso Galdós. No bastó la moda española en la época romántica para que la figura del guerrillero hispánico diera pábulo a un sentimiento unánime de admiración asombrosa. ${ }^{22}$

Aymes' suggestion that this reluctance was a form of instinctive selfcensorship is understandable in a culture which had been, quite recently, comprehensively defeated by guerilleros hispánicos. It ought to be no surprise, therefore, that Victor Hugo's Hernani, où l'honneur castillan is set safely in the sixteenth century with a bandit hero who proves to be a nobleman in disguise. The first performance prompted a traditionalistsversus-Romantics dramaturgical polemic and for a time the play was wildly successful. ${ }^{23}$ However, it has not survived changing theatrical tastes. Adapted for Italian opera in by Giuseppe Verdi and the librettist Francesco Maria Piave, it became Ernani in 1844, in which form it has remained in the repertoire to the present day.

A decade younger than Alexandre Dumas père and Victor Hugo and, as Aymes suggests, perhaps turning his back on the Napoleonic defeat, Théophile Gautier approached Spain with a tourist's eye, homing in on the ever popular and fascinating combination of Catholic Church, Moorish heritage and Castilian Reconquest on the one hand and the popular traditions of gypsies and the bullfight on the other. His Voyage en Espagne, published four years earlier than Dumas' account in 1843, was the first and most successful of a series of travelogues describing journeys which took him across North Africa, the Mediterranean and into Russia. While serving up an entertaining diet of peasant custom, he does remind his mainly middle-class reader that the traveller coming in search of the exotic and the picturesque will be disappointed, for example, in a city such as Granada to discover that the Spanish bourgeoisie are at pains to identify themselves as being as proper as any northern burgher, even if their city lacks the

22 Jean René Aymes cites Marta Giné, Francia mira la Guerra de la Independencia: la guerra en la literatura francesa del siglo XIX: Hugo, Balzac, Stendhal (Lleida: Milenio, 2008); La Guerre d'Indépendance espagnole dans la littérature française du XIXe siècle: l'épisode napoléonien chez Balzac, Stendhal, Hugo (Paris: L'Harmattan, 2008) ('Pérez Galdós y la guerra de la independencia: las inevitables ignorancias del autor', in Galdós y la gran novela del siglo XIX. IX Congreso Internacional Galdosiano, Las Palmas de Gran Canaria, 15-19 de junio de 2009, ed. Yolanda Arencibia \& Rosa María Quintana [Gran Canaria: Ediciones del Cabildo de Gran Canaria, 2011], $<$ http://actascongreso.casamuseoperezgaldos.com/index.php/cig/article/view/2076/2534> (accessed 26 April 2017). [NB. We have expanded your bibliographical information here and updated/corrected the hyperlink -- your original link did not work - \& given our date of last access.]

23 See David Falkayn, A Guide to the Life, Times and Works of Victor Hugo (Honolulu: Univ. Press of the Pacific, 2001), for a sense of the contemporary reception of Hernani: 'Those fine exaggerations with their heroic Castilian colouring, that superb Spanish emphasis, that language so lofty and imperious [...] threw us into a sort of ecstasy' (116). 
conveniences of industrialization. ${ }^{24}$ The staid uniform of the Western professional is their means of distancing themselves from the colourful barbarism the tourist has come in search of:

Les gens que l'on rencontre en costume moderne, coiffés de chapeaux tromblons, vêtus de redingotes à la propriétaire, vous produisent involontairement un effet désagréable et vous semblent plus ridicules qu'ils ne le sont; car ils ne peuvent réellement pas se promener, pour la plus grande gloire de la couleur locale, avec l'albornoz more du temps de Boabdil ou l'armure de fer du temps de Ferdinand et d'Isabelle la Catholique. Ils tiennent à honneur, comme presque tous les bourgeois des villes d'Espagne, de montrer qu'ils ne sont pas pittoresques le moins $\mathrm{du}$ monde et de faire preuve de civilisation au moyen de pantalons à sous-pieds. Telle est l'idée qui les préoccupe: ils ont peur de passer pour barbares, pour arriérés, et, lorsque l'on vante la beauté sauvage de leur pays, ils s'excusent humblement de n'avoir pas encore de chemins de fer et de manquer d'usines à vapeur. ${ }^{25}$

Earlier in his journey, his somewhat mischievous disparagement of the dress of the female aristocracy he encounters at society soirées acknowledges the same expectation but with a contradictory conclusion. Censuring their lack of exposure to Paris fashions, he observes that even those ladies who are duchesses twice over, having forgotten how to dress in the Spanish manner and not yet having learned how to do so in the French, affect a toilette which would put the most humble Parisienne seamstress to shame. ${ }^{26}$ This comment suggests disappointment that the female aristocracy no longer dresses in the late eighteenth-century castiza manner, depicted for example in Goya's tapestry cartoons, while showing all too much willingness to demote the Spanish nobility to a second tier when it comes to cosmopolitan accomplishment.

Yet, however much his narrative acknowledges the external demand for an atavism unadulterated by pretentions to modernity, when it comes to bandits Gautier places a caveat around the local status of these outlaws. He

24 Théophile Gautier, Voyage en Espagne (Paris: Charpentier et Cie, 1875), 108.

25 'The people one meets wearing modern dress, stovepipe hats, fully-buttoned frock coats, produce involuntarily a disagreeable effect on you and seem to be more ridiculous than they actually are; because they cannot really walk about, for the greater glory of local colour, wearing the Moorish albornoz of the time of Boabdil or the iron suit of armour of the time of Ferdinand and Isabella the Catholic. It is a point of honour with them, as with all the bourgeois of the cities of Spain, to show that they are not the slightest bit in the world picturesque and to prove their degree of civilization through trousers with footstraps. This is the idea which concerns them: they are afraid of being taken for barbarians, for backward people, and when one praises the savage beauty of their countryside, they excuse themselves humbly for not yet having railroads and lacking steam-powered factories' (Gautier, Voyage en Espagne, 205-06; my translation).

26 Gautier, Voyage en Espagne, 108. 
finds a respect for the bandit in the Andalusian countryside similar to that identified by Dumas in the Mezzogiorno while, like his compatriot, also denoting these figures as common criminals. He describes his journey in the environs of Écija, El Tempranillo's domain, thus:

La famille avec laquelle nous faisions roule était celle d'un ingénieur assez instruit et parlant bien français: elle était accompagnée d'un grand scélérat de figure hétéroclite, autrefois brigand dans la bande de José Maria, et maintenant surveillant des mines. Ce drôle suivait la galère à cheval, le couteau dans la ceinture, la carabine à l'arçon de la selle. L'ingénieur paraissait faire grand cas de lui; il vantait sa probité, sur laquelle son ancien métier ne lui inspirait aucune inquiétude; il est vrai qu'en parlant de José Maria, il me dit à plusieurs reprises que c'était un brave et honnête homme. Cette opinion, qui nous paraîtrait légèrement paradoxale à l'endroit d'un voleur de grand chemin, est partagée en Andalousie par les gens les plus honorables. L'Espagne est restée arabe sur ce point, et les bandits y passent facilement pour des héros, rapprochement moins bizarre qu'il ne le semble d'abord, surtout dans les contrées du Midi, où l'imagination est si impressionnable; le mépris de la mort, l'audace, le sang-froid, la détermination prompte et hardie, l'adresse et la force, cette espèce de grandeur qui s'attache à l'homme en révolte contre la société, toutes ces qualités, qui agissent si puissamment sur les esprits encore peu civilisés, ne sont-elles pas celles qui font les grands caractères, et le peuple a-t-il si tort de les admirer chez ces natures énergiques, bien que l'emploi en soit condamnable?27

Gautier's extended definition of the 'impressionable imagination' of the 'little civilized' spirits, the poor and uneducated, in other words, of a land, Andalusia, which has remained 'Arab in character' is as consonant with Washington Irving as it is with Mérimée, indulgent of the cult of the bandit, if not always of the bandit himself. Both Mérimée and Gautier

27 'The family we were travelling with was that of a rather well-educated engineer who spoke good French; they were accompanied by a large, raggle-taggle scoundrel of a man, once a brigand in José María's gang and now a mines watchman. This character followed the diligence on horseback, his knife in his waistband, his carbine on the pommel of his saddle. The engineer seemed to have a very good opinion of him; he made much of his honesty, regarding which his former occupation did not cause him the least worry; it is true that in speaking of José Maria, he told me on several occasions that he was a good and honest man. This view, which would seem to us somewhat paradoxical when applied to a highway robber, is common in Andalusia amongst the most honourable people. Spain has remained Arab in this regard, and bandits are taken easily there for heroes, an approximation which is less bizarre than it may at first appear, above all in the Meridional lands, where the imagination is so impressionable; disdain for death, audacity, detachment, alert and intrepid determination, skill and strength, all these qualities, which act so powerfully on spirits as yet little civilized, are they not those which form great personalities, and are the people so wrong to admire them in these energetic natures, even if their employment of them is to be condemned?' (Gautier, Voyage en Espagne, 292-93; my translation). 
provide learned, detailed, tolerant but not uncritical panoramas of the lives of the poor, mainly the peasantry, in Andalusia. They look kindly on the Andalusian peasantry's collusion with banditry, seeing in it a reductive kind of naïveté, while reserving judgment on the bandits themselves. However, Dumas père's more caustic response to banditry, viewed through the lens of his own father's involvement in a complex, long-lasting European war and his falling victim to a victorious citizen army, with inevitable criminal elements, presents issues which his co-eval and fellow general's son, Victor Hugo, does not attempt to address. In Gautier's account, bandits are 'easily taken for heroes' by the most upright of nonmoneyed Spaniards, and are given credit as champions of the oppressed. However, the view in Spain is not so simple and indeed Galdós' 'fresco histórico-novelesco' is nothing like as positive as Aymes might suggest, particularly when it comes to the involvement of bandits in Spanish resistance during the War of Independence. It is closer, in effect, to the cynicism of Dumas' Sainte-Hermine.

\section{Spanish Bandits: The View from Within}

Benito Pérez Galdós' account of the derring-do of Dumas' Spanish 'bandit', Juan Martín, El Empecinado (1874) takes the trouble to clear up some of the confusion regarding the make-up of Spanish guerrilla forces during the War of Independence. ${ }^{28} \mathrm{He}$ explains that three types of leadership emerged:

El guerrillero, el contrabandista, el ladrón de caminos. El aspecto es el mismo; sólo el sentido moral los diferencia. Cualquiera de esos tipos puede ser uno de los otros dos sin que lo externo varíe, con tal que un grano de sentido moral (permítaseme la frase) caiga de más o de menos en la ampolleta de la conciencia. Las partidas que tan fácilmente se forman en España, pueden ser el sumo bien o mal execrable. ¿Debemos celebrar esta especial aptitud de los españoles para congregarse armados y oponer eficaz resistencia a los ejércitos regulares? ¿Los beneficios de un día son tales que pueden hacernos olvidar las calamidades de otro día? Esto no lo diré yo, y menos en este libro, donde me propongo enaltecer las hazañas de un guerrillero insigne, que siempre se condujo movido por nobles impulsos, y fue desinteresado, generoso, y no tuvo parentela moral con facciosos, ni matuteros, ni rufianes, aunque sin quererlo y con fin muy laudable, cual era el limpiar a España de franceses, enseñó a aquéllos el oficio. ${ }^{29}$

28 See Gonzalo Sobejano, 'Bandoleros, aventureros, guerrilleros', Bilingual Review/La Revista bilingue 29:2-3 (2008-2009), 59-66 (p. 60) for a discussion of the origin of the word guerrillero in Spain in 1808.

29 Benito Pérez Galdós, Juan Martín, El Empecinado (México D. F.: Porrúa, 1975), 22. [Does this modern edition have a named editor or introduction? If so, please give details.] No editor. 
This explanation demonstrates how the French perception, voiced by Dumas père, that El Empecinado must be a bandit because he used the methodology of banditry in the era of the invention of guerrilla warfare, developed. Thirty years after the publication of Gautier's Voyage en Espagne, Galdós' reasoned views on the drawbacks of smuggling and banditry, and the apparent ease with which Spaniards formed groups to take on regular armies offer a sobering counterpoint to Gautier. Indeed, Galdós' account of El Empecinado's military career itself is anything but hagiographic. As Peter Bly observed:

Galdós se fija, no en la gran capacidad organizadora del guerrillero, sino más bien el los problemas, finalmente irresolubles, que le plantean sus capitanes más importantes [...] Juan Martín padece del vicio de la 'embriaguez guerrera' que le aparta de la realidad del resto del pueblo español. 30

This is a criticism of his generalship, not of his high-mindedness or his real achievements as a soldier. It does, however, underline the sinister legacy of the political legitimization of bandits between 1808 and 1814 .

An even more instructive perspective on the life of the ordinary Andalusian bandit is presented by the internationally best-selling Vicente Blasco Ibáñez in a novel, Sangre y arena (1908), published coincidentally a century after the French invasion. It ostensibly offers up a tourist-friendly mélange of religion, flamenco, bullfighting and banditry only to debunk each and every one of the tópicos as the novel progresses. The novel is set in the late nineteenth century, when bullfighting was at the height of its popularity. In the chapter in which the bandit character, Plumitas, is first referred to, there is even a mention of El Tempranillo, when the Marqués de Moraima remembers his late father having eaten a couple of times with him. In the Marqués' opinion, the bandits are poor wretches who have taken to robbing out of desperation or poverty: "probes muchachos que han tenío una desgrasia y se van ar campo'. ${ }^{31}$ Plumitas, when he appears, turns out to be the antithesis of Galdós' compact, bronzed Herculean Empecinado, who unites the 'energía, la actividad, la Resistencia, la contumacia, el arrojo

30 Peter A. Bly, 'On Heroes: Galdós and the Ideal of Military Leadership', Revista Canadiense de Estudios Hispánicos, 10:3 (1986), 339-351 (p. 339). [Please check your page reference - it is outside the page range of this article.]

31 Vicente Blasco Ibáñez, Sangre y arena (Madrid: Alianza, 1998), 168. [Does this modern edition have a named editor or introduction? If so, please provide this information.] No editor. The Marqués' Andalusian accent, in contrast to the standard Castilian spoken by his much-travelled niece, Doña Sol, may be indicative of what Claver Estebán designates the 'aplebeyamiento' of some elements of the Spanish nobility since the eighteenth century, in a search to appropriate a more castizo identity, of the sort mentioned by Gautier. See José María Claver Estebán, 'Sangre y arena (1916)', in his Luces y rejas: estereotipos andaluces en el cine costumbrista español (Sevilla: Fundación Pública Andaluza, 2012), 260-70 (p. 263). 
frénetico del Medio día junto con la paciencia de la raza del Norte'. ${ }^{32}$ Blasco's outlaw is instead:

[...] un hombre de mediana estatura, más bien bajo que alto, carilleno, rubio y de miembros cortos y fuertes. Vestía una blusa gris adornada de trencillas negras, calzones oscuros y raídos, con grueso refuerzo de paño en la entrepierna, y unas polainas de cuero resquebrajado por el sol, la lluvia y el lodo. Bajo la blusa, el vientre parecía hinchado por los aditamentos de una gruesa faja y una canana de cartuchos, a la que se añadían los volúmenes de un revólver y un cuchillo atravesados en el cinto. En la diestra llevaba una carabina de repetición. Cubría su cabeza un sombrero que había sido blanco, con los bordes desmayados y roídos por las inclemencias del aire libre. Un pañuelo rojo anudado al cuello era el adorno más vistoso de su persona. ${ }^{33}$

While his fair hair might link him to the posters of José Maria cited in Mérimée's Carmen, every other aspect of his battered and weather-beaten appearance is destined to disappoint the Romantic expectations of another character in Blasco Ibáñez's novel, Doña Sol, a cosmopolitan, aristocratic widow and niece of the Marqués de Moraima. Having returned to Andalusia after a long absence in the major European capitals, she wishes to re-connect with Spanish folk traditions. However, her expectations, as described somewhat sardonically by the narrator, are informed more by stagings of Bizet's opera Carmen (1875) she probably saw during her years on the European diplomatic circuit than by any connection she herself has at this point with Andalusian reality:

¡El Plumitas! Este nombre evocaba en su imaginación la figura completa del bandido. Casi no necesitaba conocerlo: apenas iba a experimentar sorpresa. Le veía alto, esbelto, de un moreno pálido, con el calañés sobre un pañuelo rojo, por debajo del cual se escapaban bucles de pelo color de azabache, el cuerpo ágil vestido de terciopelo negro, la cintura cimbreante ceñida por una faja de seda purpúrea, las piernas enfundadas en polainas de cuero color de dátil: un caballero andante de las estepas andaluzas, casi igual a los apuestos tenores que ella había visto en Carmen abandonar el uniforme de soldado, víctimas del amor, para convertirse en contrabandistas. ${ }^{34}$

Blasco's Plumitas is a long way from the War of Independence bandit heroes or their immediate successors such as El Tempranillo. Formerly a sacristan, he became an outlaw after killing one of a pair of Guardias Civiles who falsely accused him of attempted robbery and tried to beat a confession out of him. He could not live with the shame of having been

32 Galdós, Juan Martín, El Empecinado, 21.

33 Blasco Ibáñez, Sangre y arena, 203.

34 Blasco Ibáñez, Sangre y arena, 209-10. 
beaten up and the taunts of his fellow villagers and so he took his revenge. He worked alone, without political allegiance or sense of a cause greater than his own survival. In the end his bones are found buried in a shallow grave in the wilderness. He left a destitute wife and four children, and no more to show for his exploits than the earth covering him. He is an antiDon José in a meticulously-researched, 'de-romanticizing' novel which uses sordid reality to take the glamour from the matador-bandit axis created in Bizet's Carmen. ${ }^{35}$

Blasco wrote the screenplay for a film adaptation of the novel, in 1916 , in collaboration with the French director Max André. The role of Plumitas, which is relatively minor in the novel, is given greater prominence in the film, to the extent that his death and the death of the hero of the novel, the bullfighter Juan Gallardo, are placed together at the end of the film. ${ }^{36}$ However, the conclusion seems to be one and the same. Claver Estebán argues that Plumitas and Gallardo are examples of working-class Spaniards who in earlier times, up and including the War of Independence, might have emerged triumphantly from poverty in the lionized roles of matador or bandit. However, they are condemned to abject failure by the corruption of post-1868 Restoration Spain, 'rémoras de una España castiza condenada al fracaso'. ${ }^{37}$

Claver Estebán's reading of Sangre y arena is steeped in socio-political reality and indeed it is this reality which forms and informs the culture of a nation in its most fundamental aspects. However, Saura and Camus set out to tell a story without any 'historical fidelity', to create an 'imaginary ambience' about a 'legend' who is also an 'ambiguous character' and they largely based it on travelogues, letters and aleluyas. ${ }^{38}$ They chose the nineteenth century in order to avoid allusion to contemporary politics and inevitable censorship or worse. Unlike Victor Hugo, theirs was not voluntary self-censorship, their older bandit figures were victors not vanquished, but they were the losers, none the less, of a peace which left them considerably more alienated than they had been before the French invasion. Like Galdós and Blasco Ibáñez, they offer a perspective on banditry which is fully aware of both the glamorizing foreign gaze, and the contradictions between it and the, usually, sordid reality it fails to reflect. Their film, despite its technical shortcomings, conveys much of this

35 Claver Estebán, 'Sangre y arena (1916)', 269.

36 Daniel Sánchez Salas argues that this may be an editorial decision taken exclusively by Max André. See Daniel Sánchez Salas, 'La novela en el cine mudo: Blasco Ibáñez y su adaptación de Sangre y arena (1916)', in Reescrituras fílmicas: nuevos territorios de la adaptación, ed. José Antonio Pérez Bowie (Salamanca: Univ. de Salamanca, 2010) 159-76 (p. 169).

37 Claver Estebán, 'Sangre y arena (1916)', 269.

38 Bartholomew, 'The Development of Carlos Saura', 22. 
complexity and it certainly has at its heart a highly ambiguous hero in El Tempranillo.

\section{El Tempranillo: Saura and Camus' Retelling}

Saura and Camus' script is set in a period coinciding more or less with the restoration of absolutism by Ferdinand VII, the Ominous Decade of 18231833. This decade saw much greater repression of the liberal opposition than between 1814 and 1820, although the scars of the War of Independence were still very much present and, if anything, compounded by the autocratic policies of the king. The parallels between Spain in 1833 and Spain in the early 1960s are obvious and Saura was well aware of them. In a 1962 interview with José Luis Egea and Santiago San Miguel he specifies his wish to make 'a film about the nineteenth century ... about a bandit ... but it was the thematics that interested me, within the social problematic of the nineteenth century, but with repercussions in terms of the situation in which we currently lived'. ${ }^{39}$ It would be reductive to suggest that the Ominous Decade was used simply as a smokescreen to disguise discussion of Franco's Spain before the beginning of destape. As is clear from Saura's comment, he and Camus were seriously committed to the post-War of Independence periodization for its own sake.

Born in 1805, José María Hinojosa (El Tempranillo) was too young to have taken an active part in resistance to the French but Llanto por un bandido is impregnated by an awareness of how involvement by bandits and smugglers in the guerrilla war altered the nature of their interaction with the state. They became, all too temporarily, freedom fighters with an investment in the postwar settlement, only for Ferdinand VII's deliberate rejection of the significance of the guerrilla effort to shunt them back onto the margins. The first scene of the film proper is set in the lair of El Lutos (the Italian actor, Lino Ventura) as he and his band mull over the consequences of the garrottings depicted in the title sequence. El Lutos, garbed as the consummate successful bandit in black trousers and bolero jacket, white shirt and purple sash, while his men wear nondescript beige motley, decides that the best option is to move further south. El Lutos himself is a prime example of a man so deeply traumatized by his experiences that he has become a monster. His nickname, El Lutos conveys as much, the bringer of mourning. In a 1968 interview with Augusto M. Torres and Vicente Molina-Foix, Saura suggests that El Lutos' destructive behaviour may be explained by the 'climate of violence' of the Ominous Decade (which he intended to demonstrate in the heavily-censored title

39 D'Lugo, The Films of Carlos Saura, 46, citing José Luis Egea and Santiago San Miguel, 'Entrevista con Carlos Saura', NuestroCine, 15 (1962), 33-35. 
sequence). ${ }^{40}$ Yet, the commentary on the executions provided by El Tuerto (José Manuel Martín) seems to indicate that the trauma is deeper in origin than the violence instituted by Ferdinand VII after his return to Spain and related to the imprint of warfare against the French. El Tuerto is the only member of the partida to sport a battle trophy (an army bicorne which is probably French in origin) and he is mightily aggrieved that the king has not seen fit to show clemency to ex-combatants: 'Se decía que a Aurelio lo iban perdonar porque había luchado contra los franceses pero subió el primero y murió como todos'. Instead, they are hunted down and killed like rabbits: 'Así es como el rey nos trata a los que lucharon contra los franceses [...] como tú y yo, Lutos'. The implication is that only he and El Lutos are veterans of the War of Independence and therefore share an understanding. Thus, when El Lutos is buried in the ground where El Tempranillo killed him in the Goyaesque cudgel fight, the others (apart from Antonio who stays to care for the gravely injured El Tempranillo) prepare to ride off, but El Tuerto takes the time to pluck some wild flowers and lay them on the grave of his dead brother-in-arms. ${ }^{41}$

This brief snatch of dialogue and El Tuerto's valedictory gesture are the only overt references to the War of Independence in the film, but they provide important framing. The 1808 French invasion was the first fullscale invasion of Iberia since the Moorish conquest in 711. Since the capitulation in 1492 of the last Moorish kingdom, Granada, Spain and Portugal had enjoyed several centuries at the pinnacle of world power as empire nations. To be invaded and governed by the French at the beginning of the nineteenth century, however complex the political issues which led to that invasion, and then effectively to be re-imagined by them in the middle of the same century and packaged for universal middle-class consumption is evidence of a double conquest, one military, the other of the imagination. It is entirely possible therefore, that one reason for the acknowledgement of the War of Independence at the opening of the film was to provide a counterbalance to the unavoidable dependence on the work of Mérimée and Gautier which Saura acknowledged in interviews. Thus, while Saura names the Japanese directors Kenji Mizoguchi and Akira Kurosawa as important influences in terms of the style he wished to achieve in Llanto por un bandido (of the two Kurosawa was the less well known in Europe at the beginning of the sixties) and while this may account for the absence of extended dialogue of the kind which would provide overt motivation or

40 Torres and Molina-Foix, 'From Black Spain to Silver Bears', 7. [Insert the title of Willem's piece in this volume.]

41 The visual reference is to Duelo a garrotazos (1820-1823), Museo del Prado, Madrid, <https://www_museodelprado.es/coleccion/obra-de-arte/duelo-a-garrotazos/2f2f2e12ed09-45dd-805d-f38162c5beaf> (accessed 26 April 2017). [This is not a requirement but it might be helpful to include this hyperlink directing readers to the image you are referring to in your text. We have given our date of last access.] 
contextualization for the characters' behaviour, the primary external stimulus is not, in fact, Japanese but French. ${ }^{42}$ In an anti-Romantic riposte, consonant with Galdós and Blasco Ibáñez, El Tempranillo's trajectory becomes that of an impenetrable anti-hero, devoid of any ennobling flourishes, the antithesis of Gautier's grand caractère.

In this vein, Saura made the point in his 1962 interview that his and Camus' intention would be to make a 'film within a popular vein', to 'introduce real Spaniards, the Spanish people and our landscape', to an international audience. ${ }^{43}$ Given the constraints of international coproduction, with an international cast playing the majority of the main roles, the 'real Spaniards' of the piece are the extras and those taking the small parts. The emphasis thus falls on the landscape, which is incontrovertibly authentic. Celebration of the Andalusian landscape is first evident in the shot showing the arrival at the bandits' lair of the young José María Hinojosa, wearing the white trousers, blouse and brown homespun manta of a campesino, and riding a white donkey. Though the young José María had come to the mountains in search of the senior bandit chief, El Lero, he is given shelter by El Lutos after correctly answering a series of questions which prove he is, in the words of Blasco's Marqués de Moraima, one of the 'probes muchachos que han tenío una desgrasia y se van ar campo'. It is at this point in the film, before he actually becomes El Tempranillo, that his attire and mount most closely resemble the famous sketch executed by John Frederick Lewis, in 1832, at the height of the bandit's fame. As he and his donkey make their way up the hill to the cave, the greyish-brown fields stretch across the mountains to infinity in a complex pattern of planted fields behind animal and rider. Repeatedly over the course of the film, Saura will take the opportunity to frame dialogue against a backdrop of rolling sierra, for example the scene in which El Tempranillo negotiates territory with El Lero (Antonio Prieto). He also invokes indigenous painterly tradition on occasion to do the same. El Lutos' lair, for example, is shot to look like Manuel Barrón y Carrillo's, La cueva del gato (1860). ${ }^{44}$

El Tempranillo is played by Francisco Rabal, whose matinée-idol good looks are framed in close-up as the camera focuses on his enigmatic gaze at crucial junctures in the narrative. This device takes the place of selfrevelatory dialogue which the perennially taciturn El Tempranillo is only

42 Bartholomew, 'The Development of Carlos Saura', 23; Antonio Castro, 'Interview with Carlos Saura', in Carlos Saura: Interviews, ed. Willem, 115-143, 118. [Insert the title of Willem's piece in this collected volume.]

43 D'Lugo, The Films of Carlos Saura, 46.

44 Manuel Barrón y Carillo, La Cueva del gato, Museo de Bellas Artes, Sevilla, $<$ http://www.museosdeandalucia.es/cultura/museos/MBASE/index.jsp?redirect=S2_3_1_1.jsp \&idpieza $=57 \&$ pagina $=4>$ (accessed 26 April 2017) [This is not a requirement but it might be helpful to include this hyperlink directing readers to the image you are referring to in your text. We have given our date of last access.] 
seen to utter once: when, having returned to visit his wife, María Jerónima (the Italian actress Léa Massari), in the guise of a priest (to the horror of his mother-in-law), he evinces the desire to retire, eventually, so that the child he has just been told is to be born "no será un campesino muerto de hambre'. He never explains his decisions and speaks only to issue orders or to reply to questions. In a more stylistically coherent film, one might be able to attribute to El Tempranillo and his band the heroic stature of Kurosawa's also rather gnomic Samurai (employed, incidentally, to combat bandits), but there is never enough of a narrative thread in the final edited version for the hero's actions to be explained adequately by the action taking place around him.

Saura commented bitterly that the censorship of the opening title scene rendered the arrival of the young José María at the bandits' lair and his development throughout the film difficult to comprehend: "without the execution scene tying down the rest of the film, one does not realise the significance of fleeing to the hills and eventually combatting an army'. ${ }^{45}$ Initially, El Tempranillo seems motivated by a sense of justice, taking it upon himself to challenge the 'brutal and monstrous' El Lutos to a fight to the death. This was after El Lutos had stabbed Jiménez, who wanted to leave the gang, as they slept round a campfire, and then raped and murdered a young aristocrat who had come to familiarize herself with her estates and was staying in one of the posadas they robbed. ${ }^{46}$ Having gained control of El Lutos' gang, a more authoritative José María and the remaining men meet with El Lero. El Lero offers him several pieces of very sound advice and baptizes him El Tempranillo in recognition of how quickly he has learnt the ways of banditry: "no te metas en políticas, trata bien a los campesinos, que te respeten o te teman, ellos están abandonados y les gusta que estemos aquí en la sierra'. El Lero is a pragmatist who realizes that politics and banditry do not mix. Later on, he takes his settlement from the government when it is offered to him and retires to live out a comfortable old age. He understands that the peasantry are dependent on the bandits as a last resort when they find themselves deprived of justice, either as a source of refuge, as was the young José María's case, or a force for redress, but does not deceive himself that this mitigates any of the inherent enmity of the state towards them.

Some time later, with his position now secure, El Tempranillo recuperates his sweetheart, María Jerónima and organizes an elaborate wedding. It is here that he is first seen in the outfit of black trousers and jacket, white shirt with frilled front, black calañés hat and purple sash that had been worn by El Lutos in his prime. His assumption of the distinguishing outfit affected by El Lutos is an indication of his success, but

45 Bartholomew, 'The Development of Carlos Saura', 24

46 Torres and Molina-Foix, 'From Black Spain to Silver Bears', 7. [Insert the title of Willem's piece in this volume. 
this does not imply adoption of El Lutos' notoriously bloody tactics. For the time being, he is a benign bandit. His gang take over the home of a wealthy family and lock them in the cellar, with the full support of the locals. El Tempranillo and his bride consummate their marriage in the austere main bedroom of the house. The wordless wedding night scene, which shows man and wife beginning to undress, he seated on the bed and she on a chair by a shrine to the Virgin and Child is one with which Saura was particularly pleased. It may indeed give a sense of how the film might have evolved had he had greater control over it or more resources at his disposal. ${ }^{47}$ The scene is followed by footage of a bawdy party downstairs in which bandits and villagers dance, clap and sing, to diegetic guitar accompaniment.

In the period following his wedding, El Tempranillo reaches the highpoint of his influence and wealth, managing an extortion racket imposed on stagecoaches, the postal service, mills and ranches throughout south eastern Andalusia, with a division of spoils and territory agreed with El Lero. However, after a gentle interlude in which El Tempranillo finds out he is to be a father, the narrative takes a bleaker turn. The pregnant María Jerónima is imprisoned, with her mother, by the migueletes (government militia). El Tempranillo stops a stagecoach in which the Marquesa de los Cerros (the French actress, Silvia Solar) is travelling, killing the driver, in order to obtain a suitable hostage by means of whom to negotiate his wife's release. Up to this point, he has made it clear that he will not tolerate unnecessary killing. The reaction of the escaped liberal, Pedro Sánchez (the French actor, Philippe Leroy) who asks him it if was necessary to kill the driver, demonstrates that this killing is both excessive and surprising in the context of his previous conduct. The Marquesa is duly swapped for the pregnant María Jerónima. He takes his wife deep into to the mountains, in the hope that she will be safe from the migueletes as she awaits the birth of their child. El Tempranillo's abandonment of his previous position on unnecessary bloodshed is depicted as a self-contained and instinctive reaction to the imprisonment of María Jerónima, taken without regard to anything greater than himself. The bandit who up to this point may have been a relatively benign figure running a well-calibrated extortion racket has now become a much more destructive force.

The final third of the film sees the introduction of politics, present already in the figure of Pedro Sánchez whom El Tempranillo came across still manacled, and in a desperate state, after his escape from government troops. Sánchez, whose disapproval grows as El Tempranillo's behaviour changes, becomes the bandits' secretary and treasurer but he never forgets his true political allegiance and ambition. When a liberal army penetrates El Tempranillo's sierra, led by the hothead Captain Valdés (Agustín

47 Torres and Molina-Foix, 'From Black Spain to Silver Bears', 8 [Insert the title of Willem's piece in this volume.]; Bartholomew, 'The Development of Carlos Saura', 23. 
González), Pedro encourages his chief to get involved, arguing that he cannot remain on the margin of what is happening in Spain. The educated, bourgeois liberal does not convince the peasant bandit leader. El Tempranillo is not prepared to contemplate anything beyond his own racketeering domain and he follows El Lero's advice in stating that such matters neither concern nor involve him: 'a mi esos pleitos no me interesan'. He does, all the same, allow the liberals on to his terrain and provides non-military assistance where necessary.

The narrative then takes a heart-breaking turn as El Tempranillo is summoned to the village where he had left María Jerónima in the care of a midwife and El Gitano (the flamenco singer, Rafael Romero). He finds the house deserted, his child stillborn and his wife dying, with regular army lying in wait for him outside. He gathers her off her deathbed, throws her across his saddle and rides headlong out of the village to the accompaniment of gunfire. He escapes but his right arm is paralysed. This double bereavement and maiming, coupled with the encroachment of government forces on his territory finally induces him to take part in a skirmish stating forcefully: 'en la sierra no, la sierra es mía'. ${ }^{48} \mathrm{El}$ Tempranillo and his men, constituting that potentially calamitous and execrable entity identified by Galdós, a fighting force capable of 'oponer eficaz resistencia a los ejércitos regulares', then save the liberal army of the fallen Valdés from defeat at the eleventh hour. El Tempranillo is induced into political action finally because what he considered to be his own exclusive domain has been encroached upon by government forces. This does not in any sense constitute a political awakening, rather a defence of his livelihood.

The distinction between El Tempranillo's introverted running of affairs in his sierra and the wider political struggle taking place in Spain during the Ominous Decade is conveyed in the film in two ways: the choice of (mainly) non-diegetic music, and editing techniques. When Pedro and his fellow captured liberals are first shown manacled and chained together under regular army escort, the soundtrack turns from indigenous flamenco voice and/or guitar (Rafael Romero and Pedro del Valle) to Carlo Rustichelli's non-diegetic, non-autochthonous orchestral score. This introduction of the orchestral score signals the intrusion of ideologicallydriven, political conflict into El Tempranillo's world. Up to that stage, the narrative had been accompanied by flamenco music, some of it integrated into the action. A sharp change is also visible in the editing of the scenes involving intruders on the sierra. The liberal chain gang escape sequence and the later battle action scene are intercut in quickfire fashion, in

48 The skirmish was supposed to have been a full-scale battle, but Saura's shoestring resources could not finance such a large-scale undertaking (see Torres and Molina-Foix, 'From Black Spain to Silver Bears', 8). [Insert the title of Willem's piece in this volume.] 
contrast to the long, slow shots favoured by Saura in the relation of El Tempranillo's intimate life. This editing may well have been undertaken to disguise the paucity of resources used in the crowd scenes but it enraged Saura and led him to declare that his film had been ruined.

After the skirmish, the focus returns to El Tempranillo and to Saura's favoured slow shot. The camera pans across the bandit's face in close-up as his gaze moves in the opposite direction across the battlefield dotted with the bodies of the slain. He then rides down to oversee the hanging of surviving government soldiers, some stripped to the waist, upside down from the rocks. As they are being left there to die, this second reference to Goya's Desastres returns the discourse once more to the effect that conflict, in this case mixed with personal revenge, has of turning men into monsters. Antonio, the great friend who nursed him after the fight with El Lutos and who is now his hombre de confianza, is disgusted: 'te has vuelto como el Lutos'.

Unlike El Lutos, the source of whose trauma is never made explicit but who was physically unscarred, El Tempranillo was maimed in a lawenforcement ambush, not military action. This renders him pitiable but not heroic. A bandit who cannot use his right arm cannot fight. He enters the skirmish with the government army as a motivator, shouting his men on but he is unable to strike a blow himself. When the offer of an amnesty comes from the king, Pedro tells him it is a good price and El Lero, who has already accepted the king's pardon, encourages him to accept: 'acabaremos nuestros días como personas respetables'. All of El Tempranillo's men are offered an amnesty and may go free. Only Pedro and El Sotillo, the youngest of the original Lutos gang, opt to remain in the mountains, not so much to carry on as bandits but to carry on the guerrilla war against the king. El Tempranillo has to commit to special conditions however: he has to agree to pursue any of his own men remaining in the mountains on behalf of the king. That he does so is testament to his weariness and his recognition that the life of a bandit is now beyond his physical ability. The penultimate scene in the film shows El Tempranillo in the black-and-purple outfit of a bandit chief, seated in his house, staring at what turns out to be the Lewis portrait of him in his pomp. In close-up, his face is scarred from the escape with his wife's body, his dead arm hangs by his side, and the soundtrack has reverted to indigenous cantaor voice and guitar. He is about to set out to capture a new gang led by Pedro and El Sotillo and knows he is doomed. The camera rests for a long moment on his still enigmatic gaze before revealing that he is seated on a stool facing the portrait. Outside, and pitifully, he has to be helped up onto his horse by Antonio. As he leaves, with his regular army escort, he issues one last instruction to the resigned Antonio, who is under no illusion as to his fate: 'Antonio, cuida de mis cosas'. The phalanx of riders is accosted by an emaciated, elderly peasant woman, clad in black, as they leave the village. She comes up to 
them complaining that it is always the peasants who suffer. Her tone of voice and gestures leave the viewer in no doubt as to her symbolic significance: death. In the mountains, El Tempranillo, despite Pedro's best efforts to deter his men from firing on him, is killed by El Sotillo. Formed under El Lutos, he has none of the middle-class liberal's qualms. The camera pulls back and the credits roll to the sound of Rafael Romero singing 'El Tempranillo se ha muerto'.

El Tempranillo meets his end at the unrepentant hands of one of his former gang members, just as El Lutos did before him. Like his predecessor, he lost sight of the bandit's unwritten code, exemplified by the grounded and comfortable survivor, El Lero who seems to have retained general respect, negotiated his own exit without offending anyone and thus avoided rendering himself expendable. The narrative shows El Tempranillo to be too worn down and too damaged to contemplate anything other than a suicide mission. Banditry and guerrilla opposition to the absolutist monarch will continue in tandem in his absence, while, as the voice of Rafael Romero reminds the viewer, El Tempranillo will be remembered in song and legend.

In this film, the figure of El Tempranillo cannot be construed as a heroic wrongdoer, partly because both the censuring of the title sequence in Spain and the post-production editing in Rome make it difficult to discern coherence in the plot, but also because in the spirit of the 1960s, the film does not attempt to represent the folk hero celebrated in legend and memorialized in Mérimée, Joseph Léopold Hugo, Gautier and others. Rather, this bandit is an individual canny and courageous enough to create a profitable extortion racket in south-western Andalusia for a time. He is however too ignorant or naïve to understand that he may have a duty to intervene in the political conflict of his own times, despite the avuncular advice of El Lero. He also lacks the guile to be able to negotiate an amnesty which ensures his own survival. Saura's creation is a taciturn anti-hero, like his predecessor El Lutos, infinitely closer to Blasco Ibáñez's much diminished late nineteenth-century loner Plumitas than to the 'Jose Maria' and 'Sons of Ecija' lauded and feared, albeit somewhat in jest, by the likes of Disraeli and Washington Irving.

At its best, Llanto por un bandido offers a moving reflection on the unknowability of taciturn and undemonstrative, conflict-scarred men such as El Lutos and El Tempranillo, the former discarded by the restored monarchy after 1814, the latter to whom 'esos pleitos' were of no interest but who was traduced by them none the less. While there are obvious parallels to be drawn, in the light of nearly two decades of Civil War grave archaeology and memorializing, with (undeclared) post-Civil War trauma in early 1960s Francoist Spain, Saura's stated intention, at the time, was twofold: to make a film that would not be heavily censored and one which would celebrate the people and landscape of Spain. The former objective 
was only partly achieved, since the censorship of the garrotting sequence robbed El Lutos and his band of relevant context. The latter objective, owing to the aggressive post-production editing of the film, succeeds only in those calmer sequences relating to El Tempranillo's rise to fame. These sequences, a visual riposte to the clichés fomented by superficial readings of early nineteenth-century travelogues and illustrations, those contested by Blasco Ibáñez, pre-figure Saura's subsequent exploration of twentiethcentury tourist clichés of Spanishness in the Flamenco Trilogy, Bodas de sangre (1981), Carmen (1983) and El amor brujo (1986) and in Sevillanas (1991). In the wake of Llanto, Saura vowed that he would never again become involved in a project in which his was not the final word. Even so, he admitted some years later, in 1968, that he might yet make another film, one more satisfying to himself, about 'bandits and about that Spanish era, because I feel passionate about it'. ${ }^{49}$ Perhaps Goya en Burdeos (1999), a Franco-Spanish co-production but one within which Saura retained artistic control, became that film over three decades later.*

49 Torres and Molina-Foix, 'From Black Spain to Silver Bears',7. [Insert the title of Willem's piece in this volume.]

* Disclosure Statement: No potential conflict of interest was reported by the author. 